\title{
THE ORIGINS OF SCIENTIFIC THOUGHT
}

\section{Introduction}

This study will analyze the origin and development of scientific thought in Antiquity, especially in the Greek World, which will largely arise thanks to the doctrines of the so-known as Presocratic philosophers, whose reflections and postulates will lay the foundations for a new form of thought that, unlike the one that existed up to that point, was freed from any magical-religious influence with the aim of providing a rational explanation to the different phenomena of nature and of the Universe.

Firstly, we will show the opinion of various authors on the naming of the term "Pre-socratic" in relation to these early philosophers and whether or not they are right to use them, and then make a brief presentation of the origins of Philosophy. Below will be the characteristics and conceptions of the most representative Pre-socratic philosophers, who will exert a strong influence on the genesis of scientific thought, with special emphasis on Xenophanes and their criticism of divinity and Greek religious tradition, which was largely configured from the conceptions of Homer and Hesiod. In relation to the above points, the particular case of the Hippocratic medicine and its characteristics and development will be dealt with in order to determine whether or not it was a genuine scientific discipline.

\section{Methodology}

Among the primary sources used for this work, it is worth highlighting the following:

- several texts by Pre-socratic philosophers collected and commented on in the work of Kirk, G. S. and Raven, J. E. entitled The Pre-socratic Philosophers. Critical history with selection of texts, translated into Spanish by J. García Fernández.

- several fragments of the Corpus Hippocraticum, commented and translated into Spanish by C. García Gual.

Regarding secondary sources used in order to provide a better and deeper understanding of the issues to be addressed in this document, they will be appropriately reflected in the bibliography.

\section{On the origin of Greek Philosophy}

Most scholars consider that the origin of philosophy and its conception as such, it is an eminently Greek creation, completely new and without any correlation in other cultures of its space-time environment, in which there was no similar manifestation. Thus, the intellectual superiority of the Greeks over other surrounding peoples was not only quantitative, but also qualitative, as it is an unparalleled intellectual creation that will enable the birth and subsequent development of scientific thought (Reale and Antiseri, 1983: 21).

According to tradition, the creator of the term "phyllo-sophia" was Pythagoras, a fact that may be plausible, although there are scholars who think that the term arose from a religious feeling that presupposed that only the gods were endowed with a certain and total possession of the truth (Reale and Antiseri, 1983:29). Based on such religious concept, the human being could only aspire to glimpse a small part of it through his love of knowledge, which will lead to the concept of philosophy. Regarding the birth of scientific thought, some researchers claim that it emerged in Miletus, birthplace of much of the Pre-socratic philosophers (Reale and Antiseri, 1983:28).

Generally speaking, for Greeks, philosophy was characterized by three essential characteristics:

- regarding their content, unlike other sciences only concerned with certain parts of reality, philosophy seeks the discovery of all things.

- the method used by philosophy aims to offer a rational response to everything that is proposed as an object of study, going beyond mere experiences to discover the principle 
of all things, for which it uses the logos. This is what makes philosophy a science. Although art or religion have tried to explain reality, unlike philosophy, they do so using myth, fantasy and faith.

- the ultimate purpose of philosophy is nothing but the desire to know and contemplation of truth. According to Aristotle, through philosophy knowledge is sought (Met.982b2122). In fact, philosophy is born once the basic needs of men have been met, which allows them to be carefree (Met.982b25).

Among the various questions to which Ancient philosophy sought to answer, reality as a whole was initially seen as Nature (physis) and Cosmos. Because of this, the first philosophers will be called physicists, naturalists or cosmologists, and will try to figure out how cosmos emerged.

\section{The philosophers of the Physis: the Pre-socratics and the Principle of All Things}

Through the term "pre-socratics", reference is made to a period in the History of Thought during which philosophy was born. On this issue there are two major questions that have raised debates, the first of which is the possibility of determining the scope and the extent to which there was an "intellectual revolution" with respect to previous thinking, especially with the emergence of Socrates and his theories. As far as the latter is concerned, it is about determining what is understood and considered as pre-socratic philosophy (Naddaf, 2006: 161).

In the opinion of A. Laks (2002:26), in many aspects Pre-socratics determined the evolution of philosophy, and according to this scholar, very few have dared to inquire about this, and if they did, it has been superficially, focusing on the theories of a particular Pre-socratic philosopher. Laks also believes that the term "pre-socratic" is a modern denomination whose origin can be found in J.A. Eberhard's Vorsokratische Philosophie, published in 1788, in which a chapter is dedicated to Pre-socratic philosophers (2002:17). Regarding its broad acceptance, Laks states that it is for three reasons (2002:24):

- Socrates, who marks an essential turning point in the History of Philosophy.

- the fragmentary nature of Pre-socratic writings that have come to this day.

- Nietzschean critique of Socrates and the association of his theories with the Pre-socratics, which in the opinion of the German philosopher is a way to question modernity by associating Socratic doctrine with "the theoretical", as opposed to "the practical " Pre-socratics.

According to Aristotle, Tales of Miletus was the founder of the first philosophical school (Met.983b7, b21), and before philosophy was born, there was philomuthia (Met.982b19), typical of poets or theologoi. For Aristotle, the fundamental difference between the two is that Tales's stance was based on observation and argumentation, while poets accepted tradition without questioning it (Met.984a1). Terms such as philosophia, philosophos and philosophein were initially associated with the acquisition of "general culture" from which knowledge would derive (Laks, 2002: 29-30).

A fragment attributed to Heraclitus states that there is a close link between History and philosophy (DK22B35), since both disciplines questioned reality. In the Hippocratic text known as The Ancient Medicine, the term "philosophy" is used for the first time to refer to a way of life or a desire that moves certain human beings towards wisdom as a whole, transcending a mere knowledge focused solely on a single subject of study (Chapter 20). It seems that there is certain evidence to suggest that, generally speaking, Pre-socratics dealt with the study of Nature, which led them to take an interest in many other different but somehow related topics. In Phaedo, Plato himself states that Pre-socratics were interested in the study of Nature, but at no point does he say that philosophy began in Miletus (Phaedo.96a7). As Laks rightly points out, these early philosophers were concerned with giving a rational response to causes that were thought to have originated in the myth, or were result of divine actions that were used to explain the origin and development of mankind and the Universe. However, it should be noted that, despite being 
encompassed in the same group, Pre-socratic philosophers offered different answers and explanations to the same subjects (2002: 27-28).

Regarding its historical context, during the 6th century BC, Ionia was considered the cradle of Greek philosophy and science, highlighting Miletus, its most important port and commercial spot. In this city lived some of the most prominent Pre-socratics...Tales, Anaximenes, Anaximander and Heraclitus. They all conceived physis as the primordial and essential reality, and they tried to understand it.

The initiator was Tales of Miletus (623-540 BC), who in addition to being a philosopher, was also a scientist and politician. We know about his thought thanks to oral tradition. Tales asserted that there is an essential principle that is the origin of all things, water. Despite how surprising Tales' proposal may seem, this can be considered the first philosophical proposition of Western Thought, Its understanding allows us to understand the importance of Tales' teachings, which will ultimately lead to the configuration of philosophy (A. Maddalena, 1937). Although arkide. understood as a principle that may never be used by Tales himself and probably was conceived some time later by his disciple Anaximander, who best expressed this.

Tradition states that Tales identified physis with water after finding that the livelihood of all things is wet, and that desiccation is the cause of its death. This statement was disputed in Antiquity, and very few sought to reduce its significance to Tales, supporting their claims in the logos. According to Tales, the majority of thinkers based their theories only in myths. Instead, Tales introduced a new conception of the divine in which reason predominates, being his ultimate goal the end of polytheism. Another statement attributed to Tales is the one that states that everything is penetrated by the primordial principle, a source of life itself, that encourages all things to endow with its soul (panpsychism).

The second Pre-socratic philosopher, and disciple of Tales, was Anaximander of Miletus (610547 BC), who composed a treatise called On Nature, regarded by some as the first Western philosophical work. Anaximander wrote it in prose, because in his view, the logos should not be oppressed by the requirements of poetry (Reale and Antiseri, 1983: 39). Like Tales, Anaximander became involved in politics, and lead an expedition from Miletus to found a colony in Apollonia ${ }^{1}$. Regarding his thought, he tried to explain the origin of everything and considered that wáter was just one of its manifestations. The arkhe is the infinite, which is an indefinite and infinite physis. Anaximander proposed the term "apeiron" to name the limitless and original principle. From a theological point of view and unlike Greek religious tradition, in which the gods did not die but they were born, Anaximander stated that the divine, just as it does not die cannot be born. This will undermine the foundations upon which the various theogonies present in Greek mythology were based. As for his conception of the world, Anaximander thought it was made up of several "opponents" that faced each other constantly.

Anaximenes (585-528 BC), disciple of Anaximander. also wrote a treatise entitled On Nature, composed in Ionic prose. He conceived the original principle as an infinite and unlimited ethereal substance, the air. Anaximenes may have been in need to introduce a new conception of physis that could allow him to study things in a more rational way than Anaximander. Due to its extremely mobile nature, air was a perfect manifestation of the eternal movement and infinite variations of the Universe. Generally speaking, Anaximenes exposed the most logical side of the Milesian school, providing a useful concept to harmonise the physis. Anaximenes' theories will be regarded by later philosophers as the best representation of Ionian thought, that will experience a revival during the 5th century $\mathrm{BC}$.

\footnotetext{
${ }^{1}$ Currently known as Sozopol (Bulgaria). It was originally founded under the name Antheia by Anaximander of Miletus on an islet near the shores of Pontus Euxeinus. Its name was changed to Apollonia due to a temple dedicated to Apollo in which there was a large statue of the god made by Calamis. Later it would be installed in the Capitoline Hill. From the 3rd century BC onwards, Apollonia will be an important trading port that maintained intense relations with other Greek cities.
} 
Unlike previous philosophers. Heraclitus (535-475 BC) was a native of Ephesus ${ }^{2}$ known for his elusive and sour personality that was also involved in politics. He exposed his theories in a work entitled once again On Nature, written in a somewhat cryptic style. His most famous formulation is the well-known panta rhei ${ }^{3}$, heavily critisiced by some of his own disciples as Cratylus ${ }^{4}$, who accussed his master for being unrigorous. Despite that, Heraclitus' doctrines marked a starting point for later (and braver) thinkers.

Heraclitus thought that there was a perennial war between opposites, and when they were able to reach harmony, the Universe was born. According to Heraclitus, fire was the essential principle and due to its eternal changing nature, we must take with the utmost care what we perceive with our senses, because they only allow us to perceive their appearance and not their true and trascending nature. Heraclitus also adopted some Orphic conceptions such as the assertion that human life implies a mortification of the soul, and for that reason, death shall be considered a liberation that implies both reward and punishment (Reale and Antiseri, 1983: 45).

\section{Xenophanes, the Elean school and the conception of divinity}

Xenophanes (580-466 BC) came from the city of Colophon ${ }^{5}$, where he lived until the age of twenty-five. During his lifetime, Xenophanes settled in several Greek colonies of Magna Graecia and travelled extensively until his death. He has been regarded as the founder of the Elean school, althought nowadays he is considered as an independent philosopher without any ties to such philosophical school. It seems he had some sort of connection with the Eleatics, but not too close, as some scholars tend to attribute the foundation of the Elean school to Parmenides ${ }^{6}$ (Reale and Antiseri, 1983 : 53).

Xenophanes' theories gravitates around his critics to the conception of divinity set previously by Homer and Hesiod. According to Xenophanes, it is imposible to understand the divine as an unity, consideration that Aristotle confirmed a an essential difference between Xenophanes and the Eleans (Met.986b20-24). Xenophanes was more interested in solving theological and cosmogonic issues, while the Eleans did so with ontological ones instead. W. Jaeger considers Xenophanes a as an intellectual revolutionary who was able to endow his interpretations in a way that made him eran the respect and admiration of his comrades, exerting, eventually, some influence over the Eleans (1998:46). Xenophanes' conception of the divine was a great impulse for Theological philosophy, focusing its attention into the study of the essence of divinity. It was a major change for Greek culture and religion, that shifted from a cosmogonic perspective forged by Homer and Hesiod, to a new paradigm.

Another important point in Xenophanes' thought is his view regarding the material world and its subordination to the divine, perception that invalidates the traditional Greek consideration of the celestial bodies and natural phenomena as clear manifestation of the gods. It can be said that

\footnotetext{
${ }^{2}$ Ancient Greek city of Asia Minor located in the present-day Turkish province of Izmir. It was one of the most important cultural, religious and commercial centers in the Aegean. Its origin dates back to the ancient city of Apasa, which according to Hittite sources, was the capital of the kingdom of Arzawa. According to Pherecydes, the city was founded by lonian settlers under the command of Androcles, son of King Codrus of Athens after expelling the leleges and carians from their lands. Instead, a legend attributes its foundation to the mythical Amazons, receiving the name of Izmir in honor of its queen.

${ }^{3}$ Philosophical concept attributed to Heraclitus by Plato (Theaetetus, $152 \mathrm{e}, 180 \mathrm{c}-\mathrm{d}$ ), whose meaning is "everything flows".

${ }^{4}$ Greek philosopher of the late 5th century BC and one of the most important members of the relativistic current. From Heraclitus panta rhei, Cratylus issued his theories, affirming that it is not possible to bathe twice in the same water (Arist. Met. 4.5, 1010 to 10-15).

${ }^{5}$ Ancient lonian city located south of Ephesus (Asia Minor(, which according to legends was founded by Haymon, although other accounts claim that they were Cretan settlers commanded by Rhacius. It was considered as Homer's birthplace and stood out for his excellent fleet and cavalry.

${ }^{6}$ Elean philosopher born between 530 and 515 BC known for a single philosophical poem from which we entitled On Nature.
} 
Xenophanes denied an "anthropomorfic religion", but not the importance of religion as such (Lang, 1991: 8).

To this day there are only 45 surviving fragments attributed to Xenophanes that makes posible to know his thought. These fragments, besides being worthy examples of Archaic Greek poetry, differ stylistically from the works of other Pre-socratic philosophers due to its poetic composition in verses. Scholars as Diels, Reinhardt or Deichgraber, clain that Xenophanes composed a poem entitled Peri physeos that may have contained much of those fragments. If that is true, its discovery would allow us a better understanding of Xenophanes' ideas and its importance (Rey de Castro, 2004: 3). It is worth mentioning the difficulties that may sometimes arise when analyzing and interpreting some fragments due Xenophanes' literary style, essential to fully understand their meaning (ibid.).

Historical evidences suggest that Xenophanes was fully aware that his doctrines were not enough to achieve an whole a fully understanding of reality, but his criticism of Greek religion made his contemporaries think about it. Xenophanes did not hesitate to point out and reprove teh excesses and mistakes that, in his opinion, characterized Greek religiosity (Rey de Castro, 2004: 5). Xenophanes thought there was a way to understand the nature of things, even though not revealed by thr gods themselves, available to any human being insterested (Xenophanes, frag.18).

His criticism of the anthropomorfic nature of Greek religion, that attributed a human appearance and psychology shared with human beings, it is explained by Xenophanes in fragment 11, accussing Homer and Hesiod of such. With that observation, Xenophanes reached the very essence of Greek culture, since both their moral and religious foundations were imbued by Homeric texts, preserved and studied for generations. According to Xenophanes, human imagination was to blame for having endowed the gods with incompatible characteristics with their nature, so there was no reason to claim that they possessed an appearance and behavior equal to humans. It would be acceptable if it had been done in order to make them more understandable, but not otherwise (frag.14). Xenophanes argues that if Homer and Hesiod were to accept the logic nature of the gods, and if animals were capable of showing us their inner essence, they would certainly represent them in the same way as they both did with the gods (frag.16).

Xenophanes did not hesitate to harshly criticice Pythagoras and his doctrine of the transmigration of souls (metempsychosis), as well as his idea of "cosmic breathing". According to Xenophanes, with such conceptions, Pythagoras endowed the gods with an anthropomorfic appearance, wich was not acceptable. He also criticized Epimenides ${ }^{7}$, because according to his own views, divinity cannot be born, die or change.

Thanks to Xenophanes, the Western idea of the divine will change, and there will be no reason to keep conceiving it according to human patterns. Xenophanes used the physis as well as Ionian cosmology to prove that it was a mistake to consider the gods as an upgraded versión of mankind. For Xenophanes divinity is nothing but the Cosmos is unique.

\section{Hippocratic medicine: origins, development and the Corpus Hippocraticum}

According to Greek mythology, medicine was transmitted to mankind by the centaur Chiron ${ }^{8}$, who had in Asclepius ${ }^{9}$ one of his most famous and reputed disciples, and whose figure would end

\footnotetext{
7 Semilegendary Cretan philosopher of the 6th century BC. Although his work has been lost, it seems that he wrote a theogony, an epic poem dedicated to the Argonauts' journey, a cosmogony and a treatise on the legendary Cretan kings Minos and Rhadamanthus.

${ }^{8}$ According to Greek mythology, he was son of Khronos and Philyra. He lived in a cave on Mount Pelion in Thessaly, and was known for being a great teacher in several disciplines, including medicine. Among his students were Achilles, Ajax, Theseus, Jason, Hercules, and Asclepius.

${ }^{9}$ Name given to the Greek god of medicine, revered in numerous places in Greece, highlighting above all Epidaurus, where a medical school would arise. It was claimed that Hippocrates was his descendant.
} 
up being divinized, erecting temples in his honor ${ }^{10}$ where the sick went to be healed through magical-religious practices.

Close to the temples of Asclepius emerged schools of medicine, being the most famous ones in Crotone, Cirene, Rhodes and Cos. Medicine would arise from different researchers and experiences that will gradually distance medical professionals from the priests of Asclepius and their practices, which will allow them to shape their own identity. Philosophy contributed to the configuration of medicine as science, highlighting contributions from Pre-socratics and sophists, whose influence is felt in some Hippocratic texts (Jaeger, 2001, IV: 5).

In Homer's times, at the end of 8th century BC, medical knowledge were collected in the socalled Homeric poems (Albarracín, 1970). However, and bearing in mind that Homeric poems are not medical texts themselves, and some scholars have argued this as a reason to discredit studies that consider the opposite (Valverde, 1986: 91). Despite this, up to 150 anatomical terms have been found in Homeric poems. It is well known that in Homeric times, there were some individuals who possessed a vast medical knowledge that allowed to develop various kinds of remedies such as anesthetics and painkillers. The use of terms as pharmakon in the aforementioned poems should be taken with utmost caution since such term could be used in an ambivalent manner, either to refer to a remedy or a poison, both being imbued with an obvious magical-religious significance ( Valverde, 1986: 92).

Although the empirical flow took an objectivist stance based on observation and experimentation, it will not come to formulate general principles or issue general conclusions. The author of the Hippocratic text entitled The Ancient Medicine, manifests in the first paragraphs a certain disdain for hypotheses related to the primordial elements (Festugiere, 1948), which has been interpreted as an attempt to distance himself from overly abstract theories or speculations about certain phenomena that show a marked mysticism (Bourgey, 1953). As important as the text is, in Valverde's opinion, the foundations of Hippocratic medicine are based solely on theories, observations and experiments carried out by Pre-socratic philosophers (1986: 94).

The first and proper philosophical demonstrations arrived to Greece mainly from Ionia, Thrace and Magna Graecia. From the last one came the Pythagorean doctrines, whose most famous exponent was Alcmeaon of Croton ${ }^{11}$, the first one to point out the importance of the brain as the center of human beings, as well as consider health as a balance between forces (Petrucelli, 1978: 192). From Sicily came Empedocles ${ }^{12}$, who proposed the existence of four elements and two forces whose balance conditioned human health.

Thracian of Selimbria, considered the master of Hippocrates, stated that physical activity and diet should be balanced and accordingly supplemented. This latter idea will be one of the main Hippocratic ideas. Subsequently, some of Socrates's own considerations will be very positive contributions, as well as necessary for scientific and medical development. Although medical practise at that time was conditioned by several religious laws, Greek medical schools tried to systematize their knowledge (Joly, 1964).

It is fully accepted that the first Greek medical schools emerged almost at the same time in two places, Cnidus and Cos, both located in Caria, in Southwestern Asia Minor. The consideration of medicine in both schools was remarkably different. In Cnidus dominated empiricism, meanwhile

\footnotetext{
${ }^{10}$ Known as asclepeion. The largest and best preserved of these temples consecrated to Asclepius is in Epidaurus. The sick came to these temples to be healed by their priests. After spending a night inside, in the following morning the sick told their dreams to a priest, who established treatment after listening.

11 Pythagorean philosopher of the 6th century BC who devoted himself to the study of medicine. He focused on clarifying the origin and development of the sensations that according to him were in the brain, and also created the so-known Pythagorean Table of Oppositions. He also elaborated the Theory of the Immortality of the Soul and identified harmony as a universal law. It is possible to read more about his doctrines in Aristotle's Metaphysics, Book I, V.

12 (495-444 BC) Greek philosopher and politician from Agrigento known by his Law of the Four Elements. According to him, health is the balance of these elements.
} 
in Cos was rationalism. In Cnidus focused in healing spesific diseaes, but in Cos they tried to embrace a broader perspective of medicine. Generally speaking, Cnidus characterized by a less elaborated form of experimentation due to tradition, but nonetheless, some of their clinical observations reveal great accuracy, althought its members did not worry too much on sharing their medical knowledge and practises.

According to Bourgey (1971), the Cnidus school used knowledge from previous generations to build up its own, instead of direct observations. In Cos was different, as they kept a large collection of texts based exclusively on observation, and tried to obtain more contributions through the application of reasoning which Hippocrates used extensively.

The collection known as Corpus Hippocraticum, contains 64 books that originally may have belonged to an unknown medical school. Some time later, all those texts were gathered in Alexandria, forming the Corpus Hippocraticum. Sadly none of them contain the names of their authors, and it has led to several speculations (Nava, 2006: 17). For the most part, all the books reflect the teachings from Cos, and in a lesser proportion from Cnidus. Some are clearly prehyppocratic, and others have been attributed to Hippocrates himself. Finally there are the socalled posthyppocratic texts, based on Hyppocrates'doctrine (Valverde, 1986: 98). Scholars like López Férez think that such distinction between texts is meaningless because there are more coincidences than differences (1986: 163).

Since Antiquity, it has been thought that the texts comprised in the Corpus Hippocraticum cannot belong to a single or the same autor, or come from the same place and time. Also, the formation of the Corpus Hippocraticum itself explains its thematic variety, but always medicine related. Among these texts it is posible to find treatises on specific diseases, medical specialities, aphorisms, doctrines on pathology, ways of diagnosing and treatments, pharmaceutical prescriptions...

Scholars like Nava think that the diversity showed by the Corpus Hippocraticum is a valid reason to consider that its true knowledge has been buried under a cluster of medical assesments without any scientific or rational foundation (2006: 18). Bourgey considers the Corpus Hippocraticum a work of fully rational medical knowledge, and whose internal scheme is based on certain and specific guidelines such as the description of diseases, but lacking didactic purpose (1953: 41). According to Lonie, these treaties are the very (and oldest) foundation of the Corpus Hippocraticum, dated to 5th century BC, and probably transmitted orally (1983: 145-161). Within these empirical texts is worth mentioning the one entitled Women's Diseases, that contains interesting observations far from being considered as "scientific" and based mostly on superstitions (Nava, 2006: 19). There are other texts that offer a more rational view, devoid of any magical or religious element, regarding some diseases and their causes.

Of the different texts that make up the Corpus Hippocraticum, the following stand out:

- The Sacred Evil: about epilepsy, a condition considered in Antiquity a divine sign. This belief was universally accepted at the time, and Hippocrates determined that it revealed to men in a surprising and incomprehensible way, but not very different from other diseases. Hippocrates thought that belief was consecuence of not having enough knowledge, and for that reason epilepsy was view as a "divine evil". In Hippocrates' opinion, those who tried to heal epilepsy using magic were impostors who contradicted themselves pretending to cure men through treachery and superstition. Hippocrates himself shows his knowledge regarding the divine, considering a mistake the common belief that human difficulties are a will from the gods. Epilepsy, as Hippocrates explains, is only a brain alteration which has a rational cause. A successful mix of wet and dry elements, as well as cold and hot ones in our daily diet can heal us without restorting to dubious magical rituals. 
- $\quad$ On the Air, the Waters and Places: there are two main tesis in this treatise. According to Reale and Antiseri, the first one is an example of the approach that medicine should have if it wants to be considered a science. It should have an internal pattern based on reason that comes from phylosophical paradigms that see the human being as an essential part of its own existence, that is possible to understand through knowledge (1983: 111). The second one is about how the socio-political estructure and its institutions can alter the living conditions of human beings.

- The Ancient Medicine: medicine emerged in a context marked by the scheme of rationality proposed by Philosophy, so the former was forced to define itself with respect to the second to avoid being absorbed. The medical schools of Magna Graecia had used the hypothesis of the four elements (water, air, fire and earth) proposed by Empedocles to explain the cause of diseases, falling into a certain dogmatism which will be denounced in this text, claiming the independence of medicine from Empedocles's thesis. Hippocrates does not deny that these elements may influence the generation of diseases, but they do so in various ways, since in Nature everything is mixed up. Reale and Antiseri indicate the ability of Hippocrates to use the postulate of Anaxagoras, "everything is in everything", which he used to disdain Empedocles (Reale and Antiseri, 1983: 112).

- Epidemics ${ }^{13}$ : this text shows the precision that Hippocrates himself demanded of medical practice and the application of positive empiricism, conceived as a systematic and orderly description of various diseases, which was the only thing that could serve as basis for medicine.

- On the Nature of Man: although Hippocratic medicine has been considered to be based on the Theory of the Four Humors ${ }^{14}$, this treatise encodes this theory in a paradigmatic way. Although in Antiquity it was attributed to Hippocrates, it appears that its author was Polybus. Although Hippocrates had spoken of humors in The ancient medicine, he had not bothered to define them, but Polybus will go further by combining the Theory of the Four Humors with the Hippocratic teachings, which was essential to the popularity of this text, which will later be supplemented by Galen with his Doctrine of Temperaments.

\section{Consideration of Hippocratic medicine as science}

As Nava points out in his article Praxis and Reflection of the Ancient physician, the positions of medical historians, as well as philologists, can be generally encompassed in two antagonistic postures. One of them argues that the texts contained in the Corpus Hippocraticum are a faithful reflection of a prescientific mentality that did not necessarily have to derive towards a scientific medicine. According to the proponents of this trend, in order for it to have been constituted as a genuine scientific discipline, there would have to be an obvious break with previous Greek medical practice. Moreover, the consideration of Hippocratic medicine as science has only hampered the advent of true medical science. The second stream thinks that there is an obvious connection between Hippocratic and modern medicine, and although they have some doubts when considering Hyppocratic postulates as scientific, they consider their method of observation as such (2006: 11-12).

This debate about the scientificity or not of Hippocratic medicine goes back almost at the same time as its appearance in the 5th century BC. An example can be seen at Plato's Symposium, where a doctor named Erixymachus argues that medicine is a téchne (Smp.186 a-c). At that time, the usefulness that could be obtained from some arts was widely questioned, and some Pre-

\footnotetext{
13 Its title should be interpreted as "visits" (Reale and Antiseri, 1983: 113).

${ }^{14}$ Medical theory which had great influence on later European physicians until the emergence of modern medicine in the mid-19th century. According to it, human beings are made up of four elements or humors. Diseases would be the result of imbalance between them (black bile, bile, phlegm and blood).
} 
socratics did not hesitate to emphasize that the experiences gained through the senses could not constitute an acceptable source of knowledge, and even ensuring that Art did not exist, because absolutely everything was subject to the whims of chance. In response to these criticisms, medical professionals reacted by setting several rules and showing their achievements, which they said they had obtained through the possession of a valid and true knowledge (Nava, 2006: 12).

Several texts in the Corpus Hippocraticum dated to the 5th century BC, begin with a defense of the validity of medical discipline as a true science. Some examples can be seen in The Ancient Medicine (VM.1), which states that all those who dare to limit the causes of disease to a few causes and question the validity of medical practice as a genuine art that is claimed in times of great need, should take into consideration that their practitioners are highly esteemed experts. Similar manifestations can also be found in other treaties such as Acute Diseases Regime, in Chapter 2.4, or in the first chapter of On Fractures.

Although in Greece medicine received more attention than in other cultures of its time, it was at first regarded as part of Philosophy, and therefore, both were based on the same doctrines. The merit of having effectively separated medicine from Philosophy is attributed, like many other medical milestones, to the semilegendary Hippocrates.

One of the most important scholars of the Corpus Hippocraticum, R. Joly, stated in his 1966 work entitled Le niveau de la Sciencia Hippocratique, that it was certainly difficult to find in the aforementioned texts something that could be considered scientific, contributing several examples of what he believes are reasoning and postures devoid of remotely scientific rigor. In Nava's view, Joly's conclusions are somewhat extreme, but they served to pique interest in the Corpus Hippocraticum, and believes that what the Belgian scholar really intended was to question the most legendary aspects of Hippocrates, and not without reason, since the legendary Greek doctor has been attributed hundreds of texts and facts that seem to call into question the veracity of a historical Hippocrates, whose figure has been blurred by numerous late biographyes written during Antiquity, apocryphal letters and in some Byzantine accounts (2006:16).

It is important to consider the attitude and methods that Hippocratic physicians followed. One of them was analogy, and thanks to deduction and knowledge of previous cases, they managed to apply a successful remedy. The chances of getting it wrong were high, but in some cases they were able to correctly determine the causes based on rational deductions (Nava, 2006: 20-21).

The author of The Ancient Medicine defends the consideration of medicine as téchne that must be freed from philosophy. If medical practice is based on philosophic postulates, it may go so far as to underestimate its own achievements and its consideration as an authentic art (Cf. caps.1-2-5). Also he does not hesitate to claim that his attitude is that of a scientist. However, he expresses concern that his peers may be concerned about more "elevated" issues and problems, and shows his opposition to all those who base his medical principles in philosophy. In his view, a good physician should care only for human beings, and to unravel their true nature. When his opinion has been formed on the basis of medical practice, he will be able to attain some knowledge about Nature (Cf. cap.20). According to Nava, these claims must have been revolutionary in the 5th century BC, and are a testament to the will to disassociate medicine from philosophy (Nava, 2006: 24).

As López Férez (1986: 167) points out, in the Hippocratic writings it is possible to realize the constant presence of the term "science", exceptionally defined by Plato and Aristotle, but taking into account that they did it from the perspective of their philosophical doctrines, considering that philosophy is the only science (Plat. Gorgias, 450c and Phaedro, 271c; Arist. Met. 981b 23-24). In Bourgey's view, medicine would be one of the most perfect disciplines in possessing an organized and effective knowledge that does not derive from mere empiricism, and possess a true scientific spirit (1953: 231 e.k.). Unlike experience, medicine cares about norms and causes, as well as its transmission and teaching to others. Hippocratic doctors proclaimed themselves as authentic professionals (téchnites), and through their science it was possible to foresee what was about to happen. 
For López Férez, the essential features that make Hippocratic medicine a true science, are (1986: 173):

- it had its own purpose, healing and preventing the onset of diseases. Hippocratic medicine knew how to do it, and required a rational knowledge of the possible causes, their effects, and be able to establish an adequate treatment.

- the conviction that the cause of diseases, as well as their remedies, are found in Nature. All diseases are subject to rational laws, and it is impossible to try to cure using irrational practices.

\section{Conclusion}

At first medicine was closely linked to philosophy, but over time it managed to build its own identity as an independent science. From the 5th century BC, Greek philosophers focused their attention on human beings, and used observation, research and their intelligence to give a rational explanation to all those natural phenomena that affected them.

The Pre-socratics had a significant influence on medicine, which will adopt a method to develop its own identity through research, data collection and analysis, assuming that their knowledge, unlike magical or religious explanations, impossible to verify scientifically and clothed in a halo of unquestionable and absolute truth, was not unalterable since a scientific theoretical system is always hypothetical and can be investigated, and change its approaches and conclusions (Sierra, 2015: 56). In other words, the main idea adopted by Hippocratic physicians from Pre-socratic doctrines was that the physis, and Xenophanes' disengagement from magical-religious beliefs in favor of reason, observation and experience.

For the Hyppocratics, the physis transcends human knowledge, so when it comes to studying diseases, it makes no sense relating them to something beyond our limits. The physys is in itself harmony, and possesses the ability to restore balance thanks to a reason accessible to human knowledge that allows a study of Nature and its changes. If these mutations are consequence of the former, they will be inescapable but, as far as the second is concerned, we can intervene to change it. Health was conceived as "good harmony" in the essence of human beings, while a disease was an alteration of that balance.

There are some scholars who doubt to consider Hippocratic medicine as a true science, and they think that it is better to speak of a pre-scientific discipline based on severa archaicl elements linked to Greek magical-religious tradition as can be seen in the Corpus Hippocraticum. Most scholars believe that Hippocratic medicine, while not strictly scientific, established the groundwork for the future consideration of medicine as science due to the effort of rationalization carried out by the Hippocratic physicians (Nava, 2006: 32). López Férez points out the presence of some archaic elements linked to magical-religious principles from which medicine would end up completely disengaged, so it is posible to consider Hippocratic medicine as the foundation of a true medical science (1986: 175). 


\section{Bibliography and internet sources}

- Dodds, E. R. (2010) [1951], Los griegos y lo irracional, Madrid: Alianza. (Páginas 7175)

- Fernández Uriel, P. (2009) "La cultura en la época arcaica griega", en: Fernández Uriel, P. Historia Antigua Universal II: el mundo griego; Madrid: UNED, pp. 451-461

"La cultura griega en los siglos V y IV a.C.", en: Fernández Uriel, P. Historia Antigua Universal II: el mundo griego; Madrid: UNED, pp. 697-708

- García Gual, C. (trad. 2008) Hipócrates: tratados hipocráticos, Madrid: Gredos

- Hernández de la Fuente, D. (2014) "La evolución del pensamiento griego: philosophia" en: Hernández de la Fuente, D.; López Melero, R.; La civilización griega; Madrid: Alianza, pp. 313-348

- Jaeger, W. (2001) "La medicina griega, considerada como paideia" en: Jaeger, W. Paideia: los ideales de la cultura griega, vol. IV; México: Fondo de Cultura Económica, pp. 5-58

(2011) "La doctrina de Jenófanes sobre Dios" en: Jaeger, W. La teología de los primeros filósofos griegos, México: Fondo de Cultura Económica, pp. 43-59

- Jouanna, J. (1992) "La naissance de la science de l'homme chez les médecins et les savants à l'époque d'Hippocrate: problèmes de méthode" en: López Férez, J. A. (ed.). Tratados hipocráticos (Estudio acerca de su contenido, forma e influencia), Madrid: UNED, pp. 45-73

- Kirk, G. S.; Raven, J. E. (1999) Los filósofos presocráticos. Historia crítica con selección de textos; Madrid: Gredos

- Laín Entralgo, P. (1972) "La medicina hipocrática", en: Laín Entralgo, P. (coord.) Historia universal de la medicina. Tomo II. Antigüedad clásica, Barcelona: Salvat Editores, pp. 73-116

- Laks. A. (2002) "Philosophes présocratiques : remarques sur la construction d'une catégorie de l'historiographie philosophique", en: Laks, A.; Louguet, C. (eds.) Quest-ce que la philosophie présocratique? Villeneuve d'Ascq: Presses Universitaires du Septentrion, pp. 17-37

- Lloyd, G. E. R. (2008) [2002]: Las aspiraciones de la curiosidad. La comprensión del mundo en la Antigüedad: Grecia y China, Madrid: Siglo XXI. (Páginas 17-26).

- López Férez, J.A. (1986) Hipócrates y los escritos hipocráticos: origen de la medicina científica; Epos: Revista de filología ${ }^{\circ} 2$, pp. 157-176

- Naddaf. G. (2006) What is Pre-socratic Philosophy? Ancient Philosophy $n^{\circ}$ 26, pp. 161179

- Nava, D.L. (2006) Praxis y reflexión del médico antiguo; Estudios Clásicos n ${ }^{\circ} 129$, pp. 11-34

- Nestle, W. (2010) "La filosofía jónica hasta Heráclito" en: Nestle, W. Historia del espíritu griego, Madrid: Ariel, pp. 57-70

- Reale, G. \& Antiseri, D. (1983) "Los orígenes griegos del pensamiento occidental", en: Reale, G. \& Antiseri D. Historia del pensamiento filosófico y científico vol. I (Antigüedad y Edad Media); Barcelona: Herder, pp. 21-37

"Los naturalistas o los filósofos de la "physis", en: Reale, G. \& Antiseri D. Historia del pensamiento filosófico y científico vol. I (Antigüedad y Edad Media); Barcelona: Herder, pp. 37-45; 53-63

"El nacimiento de la medicina como saber científico autónomo", en: Reale, G. \& Antiseri D. Historia del pensamiento filosófico y científico vol. I (Antigüedad y Edad Media); Barcelona: Herder, pp. 107-114

- Rey de Castro, J. (2004) La teología de Jenófanes de Colofón http://www.clerus.org/clerus/dati/2004-06/22- 15/filjelo.html (accessed on April 2017)

- Sierra Martín, C. (2015) Purificadores y médicos: el vínculo entre lo humano y lo divino en época arcaica y clásica; Revista Classica, v. 28, n. 1, p. 47-71 
- Valverde López, J.L. (1986) "El período helénico", en: Folch, G. (coord.) Historia General De La Farmacia. El medicamento a través del tiempo (vol.I); Madrid: Ediciones Sol, pp.89-117

- Van der Eijk, P.H. (2005) "The 'theology' of the Hippocratic treatise On the Sacred Disease" en: Medicine and Philosophy in Classical Antiquity. Doctores and Philosophers Dónde Nature, Soul, Health and Disease, New York: Cambridge University Press, pp. 45-73. 